\title{
PARENTING ISLAM DALAM MENEKAN KECANDUAN GAME ONLINE PADA REMAJA
}

\author{
Iqbal Bafadal ${ }^{1}$, Hilda Safriani ${ }^{2}$ \\ 1,2Universitas Islam Negeri Mataram \\ 1Email: iqbalbafadal@uinmataram.ac.id \\ 2Email: safrianihilda@gmail.com
}

\begin{abstract}
Abstrak: Penelitian ini dilatar belakangi oleh perhatian penulis terhadap kecanduan game online pada diri remaja. Fokus yang dikaji dalam penelitian ini adalah bagaimana metode parenting islam dalam menanggulangi remaja yang kecanduan terhadap game online. Penelitian ini menggunakan pendekatan kualitatif melalui pengumpulan data dengan tehnik wawancara, observasi dan dokumentasi yang dianggap sangat relevan dalam mengungkap kondisi dan fenomena kecanduan remaja terhadap game online sesuai dengan keadaan dan kondisi di lapangan. Hasil penelitian ini menujukkan bahwa remaja membutuhkan waktu yang lama untuk bermain game online yang dimulai dari 3 jam hingga 18 jam setiap harinya sehingga dapat mengganggu aktifitas-aktifitas yang lainnya, pola asuh yang lemah dari orang tua memberikan kesempatan bagi anak dalam bermain game online seluas-luasnya, serta metode parenting islam yang dilakukan dan diberikan secara maksimal oleh orang tua dapat menekan kecanduan dan ketergantungan terhadap game online melalui metode keteladanan, pembiasaan, nasihat, perhatian, dan hukuman.
\end{abstract}

Kata Kunci: Parenting Islam, Kecanduan, Game Online, Remaja.

Title: Islamic Parenting in Removing Addication to Online Gamnes in Adolescent

Abstract: This research is motivated by the author's attention to online game addiction in adolescents. The focus studied in this study is how the Islamic parenting method in tackling teenagers who are addicted to online games. This study uses a qualitative approach throngh data collection with an interview, observation, and documentation techniques which are considered very relevant in revealing the conditions and phenomena of adolescent addiction to online games by the circumstances and conditions in the field. The results of this study show that teenagers need a long time to play online games starting from 3 hours to 18 hours every day so that it can interfere with other activities, weak parenting from parents provides opportunities for children to play online games as widely as possible. The breadth, as well as the Islamic parenting method that is carried out and given maximally by parents, can suppress addiction and dependence on online games through exemplary methods, babituation, advice, attention, and punishment.

Keywords: Islamic Parenting, Addiction, Game Online, Adolescent. 


\section{PENDAHULUAN}

Game online telah menjadi salah satu sarana hiburan baru yang akrab di kalangan masyarakat Indonesia. Berdasarkan versi Newzoo, player game online di Indonesia pada tahun 2017 berjumlah 43,7 juta . ${ }^{1}$ Pada awal mula pesatnya perkembangan internet, Asosiasi Penyelenggara Jasa Internet Indonesia (APJII) pada tahun 2014, mengatakan pengguna internet aktif tahun 2014 mencapai 107 juta pengguna. ${ }^{2}$ Dari data tersebut pengguna internet aktif pada tahun 2014, diperkirakan pemain game online di Indonesia berkisar 10,7 juta orang atau sekitar 10\% dari total pengguna internet. Data statistik dunia 2015 mencatat pengguna game online sebanyak 49,1 miliar. Berdasarkan penelitian profil pengguna internet dari 143,26 juta pengguna internet di Indonesia sejumlah 10,1\% merupakan pengguna game online. ${ }^{3}$

Situs resmi game online Indonesia yaitu detiknet menyatakan bahwa pada tahun 2010 terdapat 50\% jumlah pengguna game online di Indonesia adalah pelajar dan mahasiswa. Berdasarkan umur pada tahun 2016 sebanyak 24,4 juta (18,4\%) pengguna internet di Indonesia berada pada rentan umur 10-24 tahun dan mengalami pertumbuhan yang signifikan di tahun 2017 dengan penetrasi 75,50\%. Intensitas pengguna internet sebanyak 43,89\% menyatakan menggunakan internet sebanyak 1-3 jam perhari, dan sebanyak 54,13\% menggunakan internet untuk bermain game online. Survei Entertaiment Software Association (ESA) dilihat dari usia penggunanya, 32\% dari pemain game adalah anak berusia dibawah 18 tahun. Dilihat dari durasi dalam bermain game, 10\% dari remaja berusia 10-18 tahun bermain game online rata-rata tiga kali dalam sehari dengan durasi 1 jam atau lebih perharinya. Dari data-data tersebut dapat ditarik suatu kesimpulan bahwa rata-rata pengguna game online baik di luar negeri maupun dalam negeri adalah usia remaja.

Angka-angka statistik tersebut dianggap cukup fantastis untuk menggambarkan pesatnya perkembangan internet di Indonesia dan menunjukkan bahwa cukup penting untuk mendapat perhatian terkait munculnya potensi permasalahan bagi pengguna internet yang mayoritasnya merupakan penduduk berusia muda dan produktif. ${ }^{4}$ Sebagaimana yang dikutip oleh Cesaria Septa Nirwanda dalam artikel yang ditulis Lemmens Jeroen S. mengadopsi dari penelitian-penelitian terdahulu menganggap bahwa para remaja lebih rentan terhadap kecanduan permainan daripada orang dewasa. ${ }^{5}$ Remaja yang mengalami kecanduan game online

\footnotetext{
${ }^{1}$ Newzoo, “The Indonesian Gamer”, dalam newzoo.com, diakses tanggal 11 juni 2021.
}

2 Asosiasi Penyelenggara Jasa Internet Indonesia-APJII, dalam https://apjii.or.id/content/read/39/27/PROFIL-PENGGUNA-INTERNET-INDONESIA-2014, diakses tanggal 14 April 2021.

3 Octa Reni Setiawati, Agin Gunado, "Perilaku Agresif pada Siswa SMP yang Bermain Game Online", Psikologi Malahayati, Vol. 1, Nomor 1, Maret 2019, hlm. 30.

4 Dewa Ayu Eka dkk, "Hubungan Pola Asuh terhadap Perilaku Game Online di SMK Kesehatan PGRI Denpasar”, Jurnal Agustus 2019, hlm. 412.

5 Cesaria Septa Nirwanda, Annastasia Ediati, "Adiksi Game Online dan Keterampilan Penyesuaian Sosial pada Remaja”, Jurnal Empati, Vol. 5, Januari 2016, hlm. 20. 
akan mengalami beberapa gejala seperti salience (berpikir tentang bermain game online sepanjang hari), tolerance (waktu bermain game online yang semakin meningkat), mood modification (bermain game online untuk melarikan diri dari masalah), relapse (cenderung untuk bermain game online kembali setelah lama tidak bermain), withdrawl (merasa buruk jika tidak bermain game online), conflict (bertemgkar dengan orang lain karena bermain game online secara berlebihan), dan problems (mengabaikan kegiatan lain sehingga menyebabkan masalah). ${ }^{6}$

Permasalahan yang timbul dari kecanduan game online pada tahap awal awal untuk mereduksinya membutuhkan intervensi keluarga untuk mencegah adanya kecanduan internet dan game online. Sikap orang tua kepada anak menjadi penting sebagai awal pencegahan kepada level kecanduan. Pemahaman mengenai cara mendidik dan menanamkan konsep yang baik mengenai kedisplinan pada remaja serta dukungan oleh pemahaman akan karakter remaja lewat pemberian perhatian dan komunikasi intens yang terjadi di dalam keluarga menjadi hal penting yang harus dipahami orang tua dalam mengajarkan kedisiplinan pada remaja.

Beberapa intervensi pencegahan yang dapat dilakukan oleh orang tua diantaranya adalah melalui penanamanan nilai-nilai keagamaa. Dr. Abdu Ilah Nashih Ulwan sebagaimana yang dikutip oleh Abdul Khakim menjelaskan bahwa perhatian orang tua terhadap anaknya merupakan asas yang terkuat dalam pembentukan manusia yang utuh. ${ }^{7}$ Selain itu, sikap dan perilaku orang tua sangat berpengaruh terhadap perkembangan seorang anak. Penanaman nilai-nilai keagamaan ini sesuai dengan pandangan dari Abdullah Nasih Ulwan terkait metode parenting dalam islam. Abdullah Nasih Ulwan menyebutkan metode pengasuhan dalam islam diantaranya adalah metode keteladanan, metode kebiasaan, metode nasihat, metode perhatian dan metode hukuman.

\section{METODE PENELITIAN}

Penelitian ini menggunakan pendekatan kualitatif dengan pendekatan naturalistic/alami dalam melihat fenomena kecanduan remaja pada game online. Proses pengumpulan data melalui tehnik wawancara, obeservasi, dan dokumentasi. Sasaran dari penelitian ini adalah remaja yang tinggal pada Taman Pagesangan Kota Mataram yang memiliki tingkat bermain game online tinggi. Sumber data primer dalam penelitian ini adalah hasil wawancara langsung dengan orang tua dan remaja. Kemudian, data skunder diperoleh melalui studi literasi yang didapatkan dari buku, dokumentasi, jurnal, artikel, serta situs internet yang berkaitan. Setelah data terkumpul, peneliti selanjutnya melakukan analisis data melalui reduksi data yang

6 Maria Agustina Lebho dkk, "Perilaku Kecanduan Game Online Ditinjau Dari Kesepian Dan Kebutuhan Berafiliasi Pada Remaja", Journal of Health and Behavioral Science, Vol. 2, Nomor 2, September 2020, hlm. 206.

7 Abdul Khakim, Miftahul Munir, "Islam Parenting: Aktualisasi Pendidikan Islam dalam Tafsir Q.S. Luqman”, Jounal of Islamic Education (JIE), Vol. 3, Nomor 2, November 2018, hlm. 205. 
diperoleh, menyajikan data dalam bentuk narasi, verifikasi data kemudian menarik kesimpulan. ${ }^{8}$

Analisa tajam penelitian ini mengacu pada pandangan Abdullah Nasih Ulwan terkait metode parenting dalam islam. Mengenai metode parenting islam, Abdullah Nasih Ulwan menyebutkan metode pengasuhan dalam islam diantaranya adalah metode keteladanan, metode kebiasaan, metode nasihat, metode perhatian dan metode hukuman. Pertama metode keteladanan ialah suatu metode yang paling meyakinkan keberhasilannya dalam mempersiapkan dari membentuk anak dalam moral, spiritual, dan sosial. Anak akan selalu meniru dan meneladani sikap dari orang dewasa. Apabila orang tua berperilaku sopan santun anak akan menirunya, dan apabila orang tua mereka berperilaku jujur anak akan tumbuh perilaku yang jujur, dan seterusnya. Dalam penelitian ini akan dilihat bagaimana keteladanan yang diperlihatkan oleh orangtua kepada anak. Kedua metode kebiasaan, orang yang berperan besar dalam mendidik anak adalah bapak dan ibunya. Kebiasaan dari orang tua dan anggota keluarga lainnya merupakan pemberi andil yang besar dalam membentuk akhlak anak. Dengan ditanamkan kebiasaan sejak dini maka ketika dewasa nanti anak akan tumbuh kembang memiliki jiwa kesadaran spiritual, kebiasaan spiritual, dan kedamaian spiritual. ${ }^{9}$ Ketiga metode nasihat, selama seseorang masih hidup di dunia tidak akan terhindar dari nasihat. Dalam metode nasihat ini anak bisa berfikir lebih baik dan mendorong anak untuk lebih maju, memiliki pedoman tentang ajaran agama Islam. Dalam penelitian ini, analisis akan melihat sejauh apa nasihat yang diberikan oleh orang tua kepada anak-anaknya. Keempat metode perhatian, orang tua harus selalu memperhatikan perilaku anak-anaknya, apabila anak melalaikan kewajiban maka orang tua akan megingatkan dengan bahasa yang halus. Mengawasi dan memperhatikan kesiapan mental dan sosial. Ibu memiliki peran memberikan cinta yang di butuhkan untuk anak-anaknya, sedangkan peran ayah ialah sebagai peran suportif, sebagai guru penasihat, sebagai pembimbing moral dan spiritual, menjadi model keteladanan, menjadi pendengar yang baik, mempersiapkan masa depan anak-anak. ${ }^{10}$ Kelima, metode hukuman, Hukuman ini diberikan kepada anak apabila anak telah melanggar aturan Islam dengan melampaui batas. Hukuman diberikan sebagai Tindakan tegas agar anak berjalan dijalan yang benar. Metode yang memberikan hukuman pada anak yaitu: memberikan hukuman dengan cinta dan lemah lembut, tidak menjaga kebiasaan anak yang salah, hukuman dilakukan agar anak mau memperbaiki diri. Dalam penelitian ini akan dilihat bagaimana orang otua memberikan hukuman kepada anak dalam mengharapkan perubahan pada diri anak.

\footnotetext{
${ }^{8}$ Iskandar, Metodelogi Penelitian dan Sosial, (Jakarta: Refrensi, 2013), hlm. 226.

9 Syaiful Bahri Djamarah, Pola Asub Orang Tua dan Komunikasi dalam Keluarga, Upaya Membangun Citra Membentuk Pribadi Anak, (Jakarta: Rieneka Cipta, 2014), hlm. 188.

${ }^{10}$ HM. Taufiqi, Religius Parenting; Hypnoteaching and Hypnotherapy for Brilian Kids, (Malang: CV Media Sutra Atiga), hlm. 64.
} 


\section{KAJIAN TEORITIS}

\section{Parenting Islam}

Parenting Islam dikenal dengan Tarbiyah al-Awlad dan berlandaskan atas prinsip tauhid, keimanan dan akhlak mulia. Orang tua mempunyai tugas bertanggung jawab untuk mengajarkan kepada anak-anaknya tentang pendidikan akhlak, pendidikan jasmani, pendidikan nalar, dan pendidikan untuk bertanggung jawab dalam masyarakat. ${ }^{11}$ Menurut Darajat, pola asuh Islam ialah suatu pengasuhan yang utuh berdasarkan sikap dan perilaku orang tua terhadap anak sejak dini meskipun dalam hal mendidik, membina, membiasakan dan membimbing anak secara maksimal berdasarkan Al-Qur'an dan Sunnah. ${ }^{12}$ Disini tugas orang tua adalah memberikan pengarahan yang positif dan memberikan bimbingan kepada anaknya agar bisa menerapkan ajaran pendidikan Islam yang benar berdasarkan perilaku yang baik.

Menurut Syifa dan Munawaroh sebagaimana yang dikutip oleh Ahmad Yani, Parenting Islam adalah suatu bentuk pola asuh yang berdasarkan nilai-nilai ajaran Islam, Al-Qur'an dan As-Sunnah. Menurut Rachman Parenting Islam adalah suatu pengasuhan anak sesuai proses tumbuh kembangnya berdasarkan Al-Qur'an dan Sunnah Rasulullah SWT. Pengasuhan ini diadakan berdasarkan ajaran agama Islam yang bertujuan memberikan kebaikan dunia dan akhirat melalui penjelasan terkait aspek-aspek pendidikan yang baik. Ahli lain mengatakan bahwa Parenting Islam adalah mencetak generasi muda yang memiliki moral dan mengacu dalam norma-norma Islam dan membentuk generasi yang sholih dan sholihah. ${ }^{13}$ Oleh karena itu, hal ini dapat dilakukan ketika anak belum lahir di dunia, bukan hanya ketika anak sudah lahir ke dunia ini. Kamal Hasan dalam Thalib mengatakan, Parenting Islam adalah suatu proses seumur hidup untuk mempersiapkan diri, dan orang bisa menjalankan perannya sebagai khalifahnya di dunia ini. Dengan kesiapan tersebut, diharapkan bisa memberikan sumbangan terhadap rekontruksi dan pembangunan masyarakat dalam mencapai kebahagiaan dunia dan akhirat. Dari beberapa pendapat tokoh diatas dapat disimpulkan bahwa Parenting Islam adalah pola asuh yang dilakukan oleh orang tua yang mendidik dan mengasuh anak berdasar pada ajaran, aturan dan nilai-nilai agama islam kepada anaknya yang bersumber pada Al-Qur'an dam Al-Hadis.

Pola asuh Islam lebih menekankan pada praktik pengasuhan, tidak hanya fokus pada gaya pengasuhan dalam keluarga, akan tetapi lebih fokus pada bagaimana orang tua membentuk insan al-kamil pada anak-anaknya. Orang tua memiliki kewajiban membimbing dan mendidik anak berdasarkan syariat agama. Islam memandang bahwa dalam membentuk

11 Tadkiroatun Musfiroh, Memilih, Menyusun dan Menyajikan Cerita Untuk, Anak Usia Dini, (Yogyakarta: Tiara Wacana, 2008), hlm. 15.

12 Z Drajat, Membina Nilai-Nilai Moral di Indonesia, (Jakarta: Bulan Bintang, 1985), hlm. 34.

13 M. Thalib, "Pola Asuh Orang Tua; Perspektif Konseling dan Al-Qur'an", Jurnal Hunafa, Vol. 4, Maret 2015, hlm. 324. 
anak yang memiliki perilaku baik itu harus diawali dari perilaku orang tua sejak dini. Islam memandang bahwa perilaku anak dimasa depan itu merupakan cerminan dari orang tua dan Pendidikan dari orang tua yang mereka ajarkan sejak dini. Abdullah Nashih Ulwan dalam Muhammad Nur Abdul Hafizh Suwaid menyebutkan pengasuhan secara Islam dibagi menjadi 5 metode, metode tersebut ialah metode keteladanan, metode kebiasaan, metode nasihat, metode perhatian dan metode hukuman. ${ }^{14}$

1. Metode Keteladanan

Metode keteladanan ialah suatu metode yang paling meyakinkan keberhasilannya dalam mempersiapkan dari membentuk anak dalam moral, spiritual, dan sosial. Anak akan selalu meniru dan meneladani sikap dari orang dewasa. Apabila orang tua berperilaku sopan santun anak akan menirunya, dan apabila orang tua mereka berperilaku jujur anak akan tumbuh perilaku yang jujur, dan seterusnya. Sebagaimana yang di kutip oleh Hikmatullah dalam hadist yang menjelaskan pernyataan di atas ialah:

"Kedua orang tua yang menjadikannya kaum Yabudi, kaum Majusi atau kaum Nasrani".15

Orang tua merupakan pengukur kepribadian anaknya. Sebagai orang tua yang baik sebelum mendidik anaknya akan lebih baik jika orang tua tersebut mendidik dirinya sendiri terlebih dahulu, karena anak merupakan imitasi dari orang tuanya, dan orang tua sebaiknya harus berhati-hati dalam berperilaku di hadapan anak-anak. Orang tua dituntut untuk menjadi suri tauladan yang baik. Dalam masa pertumbuhan anak selalu memperhatikan sikap dari orang tuanya, dan orang tua lah yang sebagai pembentuk karakter anak.

Ayah memiliki peran menanamkan kedisiplinan terhadap anak, mendorong anak agar bisa menghadapi kehidupan, meningkatkan rasa kepribadian anak. Ibu juga memiliki peran untuk menanamkan rasa nyaman kepada anak, mendidik anak untuk memiliki rasa mau menerima dengan keadaan. Sifat keteladanan ini akan lebih cepat berkembang mempengaruhi tingkah laku dari anak. Keteladanan ini berpengaruh lebih besar Ketika anak berusia 6 tahun kedepan, karena pada usia ini membentuk dasar untuk dewasa nanti. Menurut Abdullah Nashih Ulwan dalam Muhammad Nur Abdul Hafizh Suwaid menjabarkan contoh bagi orang tua yaitu sikap keteladanan dalam beribadah, sikap murah hati, sikap sopan santun, sikap rendah hati, sikap pemberani, sikap teladan dalam berakidah. ${ }^{16}$

14 Muhammad Nur Abdul Hafizh Suwaid, Prophetic Parenting: cara Nabi SAW mendidik anak, (Yogyakarta: Pro-U Media, 2010), hlm. 140.

${ }^{15}$ Hikmatullah, Teguh Fachmi, "Keteladanan Orang Tua dalam Islam", Jurnal Pendidikan Agama Islam, Vol. 07, Nomor 2, Juni-Desember 2020, hlm. 166.

16 Muhammad Nur Abdul Hafizh Suwaid, Prophetic Parenting: cara Nabi SAW mendidik anak, (Yogyakarta: Pro-U Media, 2010), hlm. 142. 
2. Metode Kebiasaan

Kebiasaan dari orang tua dan anggota keluarga lainnya merupakan andil yang besar dalam membentuk akhlak anak. Dengan ditanamkan kebiasaan sejak dini maka ketika dewasa nanti anak akan tumbuh kembang memiliki jiwa kesadaran spiritual, kebiasaan spiritual, kedamaian spiritual. ${ }^{17}$ Anak merupakan cerminan dari kedua orang tuanya karena anak peniru terbaik dari lingkungan sekitarnya. Oleh karena itu orang tua memiliki peran penting untuk memperhatikan anaknya dan berperilaku baik di hadapan anak, apabila aorang tua menginginkan anak yang memiliki tingkah laku yang baik dan kebiasaan yang baik, maka orang tua memiliki tugas mendidik anaknya sedini mungkin dan menanamkan moral yang baik terhadap anak. Sebagaimana yang di kutip oleh M. Burhanuddin Ubaidillah dalam hadist yang menjelaskan pemaparan di atas ialah:

"Perintabkan anak-anakmu menjalankan ibadah shalat jika mereka sudah berusia tujuh tahun.

Dan jika mereka sudah berusia sepuluh tabun, maka pukullah mereka jika tidak mau melaksanakannya dan pisabkan tempat tidur mereka". ${ }^{18}$

Apabila anak bisa tumbuh kembang di lingkungan yang tepat, anak akan mendapatkan arahan, bimbingan dan kasih sayang terhadap anggota keluarga lainnya, maka anak akan tumbuh dengan akhlak yang baik. Contoh kebiasaan yang harus diterapkan kepada anak diantaranya adalah memberikan salam ketika akan keluar atau masuk rumah, mengajarkan tata cara perilaku yang baik, biasakan shalat dan mengaji didekat anak, mengajarkan kedisiplinan, kemandirian, berkomunikasi yang baik.

3. Metode Nasihat

Dalam metode nasihat ini anak bisa berfikir lebih baik dan mendorong anak untuk lebih maju, memiliki pedoman tentang ajaran agama Islam. Menurut Abdullah Nashih Ulwan dalam Muhammad Nur Abdul Hafizh Suwaid memberikan nasihat di bagi menjadi 3; pertama, menarik perhatian agar memberikan kepuasan dan kelembutan atau penolakan, ${ }^{19}$ Kedua, metode cerita dengan di sertai tamsil ibarat dan nasihat. Dalam metode ini ada pengaruh terhadap jiwa dan akal anak, karena anak suka akan cerita-cerita, seperti cerita dogeng, cerita tentang Nabi. Orang tua harus telaten dalam membacakan cerita kepada anak, orang tua memberikan cerita yang berkaitan tentang perilaku yang baik dan menyentuh perasaan anak. Ketiga, pengarahan Al-Qur'an dengan wasiat dan nasihat. Al-Qur'an dipenuhi dengan ayat-ayat tentang wasiat dan nasihat yang mengandung arahan pada pembaca untuk mendatangkan manfaat dalam agama maupun

${ }^{17}$ Syaiful Bahri Djamarah, Pola Asub Orang Tua dan Komunikasi dalam Keluarga, Upaya Membangun Citra Membentuk Pribadi Anak, (Jakarta: Rieneka Cipta, 2014), hlm. 188.

18 M. Burhanuddin Ubaidillah, "Pendidikan Islamic Parenting dalam Hadith Perintah Salat", Jurnal Darussalam: Jurnal Pendidikan, Komunikasi dan Pemikiran Hukum Islam, Vol. 10, Nomor 2, April 2019, hlm. 351.

19 Muhammad Nur Abdul Hafizh Suwaid, Probetic Parenting: cara Nabi SAW mendidik anak, (Yogyakarta: Pro-U Media, 2010), hlm. 144. 
akhirat yang bisa membentuk spiritual, mental ataupun fisik. Orang tua memiliki kewajiban memberikan Pendidikan yang terbaik untuk anaknya, agar kelak bisa menjadi anak yang shaleh, sholehah dan taat menjalankan perintah-Nya. Salah satu cara agar anak ingat menjalankan ajaran Allah ialah orang tua agar selalu memberikan pengarahan dalam waktu yang tepat.

4. Metode Perhatian

Orang tua harus selalu memperhatikan perilaku anak-anaknya, apabila anak melalaikan kewajiban maka orang tua akan megingatkan dengan Bahasa yang halus. Mengawasi dan memperhatikan kesiapan mental dan sosial. Ibu memiliki peran memberikan cinta yang di butuhkan untuk anak-anaknya, sedangkan peran ayah ialah sebagai peran suportif, sebagai guru penasihat, sebagai pembimbing moral dan spiritual, menjadi model keteladanan, menjadi pendengar yang baik, mempersiapkan masa depan anak-anak. ${ }^{20}$ Dalam perhatian terdapat beberapa aspek antara lain: keimanan anak, moral anak, mental dan intelektual anak, jasmani anak, psikologi anak, sosial dan spiritual anak.

5. Metode Hukuman

Rasulullah mengatakan memberikan hukuman terhadap anak boleh akan tetapi tidak boleh melakukannya dengan sembarangan. Hukuman ini diberikan kepada anak apabila anak telah melanggar aturan Islam dengan melampaui batas. Hukuman diberikan sebagai Tindakan tegas agar anak berjalan dijalan yang benar. Metode yang memberikan hukuman pada anak yaitu: memberikan hukuman dengan cinta dan lemah lembut, tidak menjaga kebiasaan anak yang salah, hukuman dilakukan agar anak mau memperbaiki diri. Ada cara yang harus diperhatikan orang tua dalam memberikan hukuman pada anak antara lain; usia mencukupi, memperhatikan kesalahan anak, hindari perkara yang meragukan, pukulan tidak menyakitkan, tidak menyertai dengan ucapan buruk, jangan menampar muka. ${ }^{21}$

\section{Remaja}

Kata "remaja" berasal dari bahasa Latin yaitu adolescene yang berarti to grow atau to grow maturity. Banyak tokoh yang memberikan definisi tentang remaja, seperti DeBrun dalam Yudrik Jahja mendefinisikan remaja sebagai periode pertumbuhan antara masa kanak-kanak dan dewasa. Menurut Papalia dan Olds dalam Yudrik Jahja, masa remaja adalah masa transisi perkembangan antara masa kanak-kanak dan dewasa yang pada umumnya dimulai pada usia 12 atau 13 tahun dan berakhir pada usia akhir belasan tahun atau awal dua puluhan tahun. ${ }^{22}$

${ }^{20}$ HM. Taufiqi, Religius Parenting; Hypnoteaching and Hypnotherapy for Brilian Kids, (Malang: CV Media Sutra Atiga), hlm. 64.

${ }_{21}$ M. Fauzul Adhim, Bersikap terbadap Anak (Pengarub Perilaku Orang Tua terbadap Kenakalan Anak), (Yogyakarta: Titian Ilahi Press, 1997), hlm. 102-115.

${ }^{22}$ Yudrik Jahja, Psikologi Perkembangan, (Jakarta: Kencana Prenadamedia Group, 2011), hlm. 219. 
Menurut Adams dan Gullota, masa remaja meliputi usia antara 11 hingga 20 tahun. Adapun Hurlock membagi masa remaja menjadi masa remaja awal (13 hingga 16 atau 17 tahun) dan masa remaja akhir (16 atau 17 tahun hingga 18 tahun). Masa remaja awal dan akhir dibedakan oleh Hurlock karena pada masa remaja akhir individu telah mencapai transisi perkembangan yang lebih mendekati dewasa.

Menurut Papalia dan Olds dalam Yudrik Jahja, berpendapat bahwa masa remaja merupakan masa antara kanak-kanak dan dewasa. Adapun Anna Freud berpendapat bahwa masa remaja terjadi proses perkembangan meliputi perubahan-perubahan yang berhubungan dengan perkembangan psikoseksual, dan juga terjadi perubahan dalam hubungan dengan orang tua dan cita-cita mereka, di mana pembentukan cita-cita merupakan proses pembentukan orientasi masa depan.

Masa remaja dianggap mulai pada saat anak secara seksual menjadi matang dan berakhir saat mencapai usia matang secara hukum. Namun penelitian tentang perubahan perilaku, sikap, dan nilai-nilai sepanjang masa remaja tidak hanya menunjukkan bahwa setiap perubahan terjadi lebih cepat pada awal masa remaja daripada tahap akhir masa remaja, tetapi juga menunjukkan bahwa perilaku, sikap, dan nilai-nilai pada awal remaja berbeda dengan pada akhir masa remaja. Dengan demikian, secara umum masa remaja dibagi menjadi dua bagian, yaitu awal dan akhir masa remaja.

Garis pemisah antara awal dan akhir masa remaja terletak kira-kira di sekitar usia 17 tahun; usia di mana rata-rata setiap remaja memasuki sekolah menengah tingkat atas. Dan melanjutkan pendidikan tinggi, mendorong sebagian besar remaja untuk berperilaku lebih matang. Rata-rata laki-laki lebih lambat matang daripada anak perempuan, maka laki-laki mengalami periode awal masa remaja yang lebih singkat, meskipun pada usia 18 tahun ia telah dianggap dewasa, seperti halnya anak perempuan. Akibatnya, sering kali laki-laki tampak kurang matang untuk usianya dibandingkan dengan perempuan. Namun adanya status yang lebih matang, sangat berbeda dengan perilaku remaja yang lebih muda. Awal masa remaja berlangsung kira-kira dari 13 tahun sampai 16-17 tahun, dan akhir masa remaja bermula dari usia 16 atau 17 tahun hingga 18 tahun, yaitu usia matang secara hukum. Dengan demikian akhir masa remaja merupakan periode yang sangat singkat. Di dalam penelitian ini remaja yang menjadi fokus penelitian adalah remaja menurut teori Hurlock yakni remaja usia 13-18 tahun.

\section{Kecanduan}

Kecanduan dalam Kamus Besar Bahasa Indonesia (KBBI) berasal dari kata candu yang berarti sesuatu yang menjadi kegemaran dan membuat orang ketagihan, maka kecanduan adalah ketagihan, ketergantungan atau kejangkitan pada suatu kegemaran sehingga melupakan hal yang lain-lain. Dalam bidang psikiatris, kecanduan merupakan fenomena yang sangat kuat. 
Seiring berjalannya waktu, istilah kecanduan tidak hanya sebatas ketergantungan terhadap zatzat adiktif. American Psychological Assosiation menjelaskan bahwa ketergantungan tidak hanya disebabkan oleh ketergantungan zat-zat adiktif, namun suatu perilaku atau kegiatan tertentu juga dapat menyebabkan kecanduan. ${ }^{23}$ Konsep kecanduan dapat diterapkan pada perilaku secara luas termasuk kecanduan teknologi komunikasi informasi. Salah satunya adalah kegiatan dalam menggunakan internet.

Kecanduan internet, sebagai sebuah psychological disorder yang relatif baru, dapat disimpulkan sebagai keinginan yang kuat atau ketergantungan secara psikologis terhadap internet. Menurut Lance Dodes dalam bukunya yang berjudul "The Heart of Addiction", terdapat dua jenis kecanduan, yaitu adiksi fisikal seperti kecanduan terhadap alkohol atau kokaine, dan adiksi non-fisikal seperti kecanduan terhadap game online ataupun terhadap internet. Kecanduan atau addiction dalam kamus psikologi diartikan sebagai keadaan bergantungan secara fisik pada suatu obat bius. Pada umumnya, kecanduan tersebut menambah toleransi terhadap suatu obat bius, ketergantungan fisik dan psikologis, dan menambah gejala pengasingan diri dari masyarakat apabila obat bius dihentikan. Kata kecanduan (addiction) biasanya digunakan dalam konteks klinis dan diperhalus dengan perilaku berlebihan. ${ }^{24}$

Berdasarkan pendapat diatas, maka kecanduan dalam konteks penelitian ini merupakan suatu kondisi dimana individu merasakan ketergantungan terhadap internet dan game online dan merasa terhukum apabila tidak memenuhi hasrat dan kebiasaannya dalam bermain game online dan akibat kurang kontrol sehingga memunculkan perilaku-perilaku negatif

\section{Game Online}

Game online adalah gabungan dari dua kata yang berasal dari bahasa Inggris. Game artinya adalah permainan dan online artinya adalah dalam jaringan. Jika dua kata ini digabungkan, maka akan terbentuk suatu makna baru yang tidak jauh dari pengertian dasar kedua kata itu. Game online adalah suatu bentuk permainan yang dihubungkan melalui jaringan internet. ${ }^{25}$ Game online merupakan salah satu hasil dari perkembangan internet dan berbentuk permainan yang berbasis elektronik dan visual. Game online dimainkan dengan memanfaatkan media visual elektronik yang melibatkan banyak pemain didalamnya, dimana permain ini membutuhkan jaringan internet.

Perkembangan game online sendiri tidak lepas juga dari perkembangan teknologi komputer dan jaringan computer itu sendiri. Dengan adanya kemajuan teknologi terutama jaringan internet, menjadi sesuatu yang menarik bagi para gamers atau sebutan bagi para

23 Tantri Widyarti Utami, "Kecanduan Game Online Berhubungan dengan Penyesuaian Sosial pada Remaja", Jurnal Keperawatan, Vol. 12, Nomor 1, Maret 2020, hlm. 18.

${ }^{24}$ Chaplin, James P, Kamus Lengakap Psikologi, (Jakarta: Rajawali Pers, 2014), hlm. 11.

${ }^{25}$ Candra Zebeh Aji, Berburu Rupiah Lewat Game Online, (Yogyakarta: Bouna Books, 2012), hlm. 1. 
maniak penggemar game untuk berkreasi di dunia online dengan game yang disukainya. Game online bagian dari internet yang sering dikunjungi dan sangat digemari dan bisa menyebabkan kecanduan yang memiliki intensitas yang sangat tinggi. ${ }^{26}$

Meledaknya game online sendiri merupakan cerminan dari pesatnya jaringan computer yang dahulunya berskala kecil (small local network) sampai menjadi internet dan terus berkembang sampai sekarang. Game saat ini semakin berkembang dan menarik untuk dimainkan. Selain menjadi sarana komunikasi sesama pengguna, game juga berguna menghilangkan rasa lelah dan jenuh setelah beraktivitas. Fitur serta grafis permainan yang semakin bagus dan nyata menjadi alasan banyak orang untuk memainkannya. Apalagi game sekarang tidak lagi hanya dimainkan dengan pilihan single player, tetapi sekarang game bisa dimainkan secara online dan bersama dengan orang lain (multiplayer).

\section{PEMBAHASAN}

\section{Fenomena di Lapangan}

Lingkungan Taman Pagesangan merupakan salah satu bagian dari Kelurahan Pagesangan Timur Kota Mataram yang sudah mendapatkan jaringan internet yang memadai untuk mengakses segala kebutuhan yang di perlukan termasuk salah satunya adalah akses untuk bermain game online. Dari hasil wawancara dan observasi yang dilakukan peneliti, ditemukan beberapa fenomena dari responden dilapangan. Beberapa diantaranya adalah

1. Durasi Bermain Game Online

Game online menyediakan berbagai macam tantangan pada setiap sesinya sehingga para pengguna merasa tertantang dengan setiap sesinya dan berusaha ingin menyelesaikan tantangan agar bisa naik level yang lebih tinggi. Untuk sampai pada sebuah level tertinggi tentu membutuhkan waktu yang tidak sebentar tidak jarang waktu menjadi hal berharga yang akan banyak tersita. Berikut hasil wawancara yang di lakukan peneliti dengan remaja yang bermain game online di Lingkungan Taman Pagesangan dalam ranah durasi bermain game online. Remaja I mengutarakan bahwa:

"Hmmm 2020 mulai mainnya. Perasaan pertama kali main bahagia. Dalam sehari main 18 jam, istirahat kalo abis main game. Istirahatnya makan, sholat terus main game. Pengen main terus kalo beberapa hari nggak main". ${ }^{27}$

Remaja II mengatakan:

${ }^{26}$ Mimi Ulfa, "Pengaruh Kecanduan Game Online Terhadap Perilaku Remaja Di Mabes Game Center Jalan HR. Subrantas Kecamatan Tampan Pekanbaru", Jurnal JOM. FISIP, Vol. 4, Nomor 1, Februari 2017, hlm. 4.

${ }^{27}$ Nabila, Wawancara, Lingkungan Taman Pagesangan, 16 Maret 2021. 
"Sehari main game online bisa 3 jam lebih, ada jeda istirahatnya. Perasaan kalo lagi main game online seneng, ngerasa tertantang. Ingin main kalo beberapa hari atau minggu nggak main game". ${ }^{28}$

Remaja III:

"Main game online dari masih 2020, oohh paling-paling sib sehari tuh cuman dari misalnya sampe, sekarang jam 7 sampe jam 9 terus lanjut lagi. Aaa berapa jam, 3 jam lebih. Seneng sih, terbibur sedikit waktu main game. Pengen sibnya main kalo beberapa minggu nggak main game”.29

Pernyataan tersebut juga di sampaikan oleh Remaja IV, ia mengatakan bahwa:

"Udah lama mainnya. Seneng waktu main, sama seneng juga mba pertama kali main. Sehari mainnya ada 4 jam, 5 jam. Kaya jenuh, pengen main terus kalo beberapa hari nggak main”.30

Pada paparan diatas dapat ditarik kesimpulan bahwa remaja banyak menyita waktu untuk bermain game online.

2. Aktivitas Terganggu atau Tertunda

Pemain akan mengorbankan waktu untuk hobby yang lain, mengorbankan waktu untuk tidur, belajar ataupun bekerja dan waktu untuk keluarga. Selain itu game online juga dapat mengakibatkan pola makan dan pola tidur yang tidak teratur, sehingga akan mengganggu kesehatan. ${ }^{31}$ Berdasarkan penemuan peneliti di lapangan remaja yang bermain game mengalami ketertundaan untuk aktivitas lainnya. Ia lebih banyak bermain game dan menunda aktivitas lainnya, seperti kegiatan shalat, makan, belajar dan lebih memilih untuk sendiri serta kurang bergaul dengan teman-temannya.

3. Pengawasan dan Batasan Waktu untuk Bermain Game Online

Menurut Smart sebagaimana yang dikutip oleh Juwi Rayfana Tiwa mengemukakan bahwa faktor-faktor yang dapat mengakibatkan kecanduan game online adalah kurang perhatian dari orang-orang terdekat, mengalami stress, kurang kontrol orang tua, kurang kegiatan, lingkungan dan pola asuh orang tua yang salah. ${ }^{32}$ Pola asuh orang tua menjadi salah satu faktor penyebab remaja mengalami kecanduan game online.

Kurangnya pengawasan orang tua berkorelasi dengan perilaku berisiko yang mengarah pada perilaku antisosial dan penggunaan zat terlarang pada remaja. Menurut Kwon, Chung dan Lee sebagaimana yang dikutip oleh Eryzal Novrialdy mengungkapkan bahwa remaja cenderung untuk meningkatkan waktu yang dihabiskan untuk permainan

\footnotetext{
28 Vira, Wawancara, Lingkungan Taman Pagesangan, 16 Maret 2021.

${ }^{29}$ Mahdisa, Wawancara, Lingkungan Taman Pagesangan, 17 Maret 2021.

30 Wisnu, Wawancara, Lingkungan Taman Pagesangan, 18 Maret 2021.

${ }^{31}$ Siprianus Koi dkk, "Pengaruh Permainan Game Online terhadap Aktivitas Belajar pada Anak Usia Sekolah Kelas III dan IV SDN Merjosari Malang", Nursing News, Vol. 2, Nomor 1, 2017, hlm. 326.

32 Juwi Rayfana Tiwa dkk, "Hubungan Pola Asuh Orang Tua dengan Kecanduan Game Online pada Anak Usia Remaja di SMA Kristen Zaitun Manado", e-journal Keperawatan (e-Kp), Vol. 7, Nomor 1, Mei 2019,
} hlm. 2 . 
internet saat merasa memiliki hubungan yang buruk dengan orang tuanya. ${ }^{33}$ Pemantauan dalam hal game online merupakan strategi efektif yang mencegah pengguna untuk terlibat tindakan penggunaan berlebihan atau tidak tepat. Orang tua harus berhati-hati dan penuh pertimbangan dalam memberikan akses terhadap berbagai produk teknologi. Para orang tua harus lebih mengawasi anak-anaknya dalam bermain game online karena bisa berpotensi membuat anak-anak menjadi kecanduan bermain game online.

Jika game online dimainkan tanpa kontrol dari orangtua, maka bisa membuat perilaku remaja dalam bermain tidak ada aturan. Pentingnya pengawasan orangtua dapat menjadi benteng membatasi kecanduan game online. Oleh karena itu orangtua yang yang bersikap acuh terhadap permainan game online remaja dapat menyebabkan dampak yang lebih buruk di masa yang akan datang. ${ }^{34}$ Hasil dari wawancara, remaja Lingkungan Taman Pagesangan lebih banyak tidak mendapat pengawasan dan batasan waktu untuk bermain game online. Kontrol orang tua pun tidak ada, salah satu remaja tidak mendapatkan kontrol dari orang tua yang dikarenakan kesibukan didalam bekerja.

\section{Metode Parenting Islam dalam Menanggulangi Remaja Kecanduan Game Online}

Pola asuh Islam lebih menekankan pada praktik pengasuhan, tidak hanya fokus pada gaya pengasuhan dalam keluarga, melainkan juga pada bagaimana orang tua membentuk insan al-kamil pada anak-anaknya. Analisa pengasuhan secara Islam dengan beberapa metode dalam menekan kecanduan pada game online diantaranya sebagai berikut:

1. Metode Keteladanan

Metode keteladanan ialah suatu metode yang paling meyakinkan keberhasilannya dalam mempersiapkan dari membentuk anak dalam moral, spiritual dan sosial. Anak akan selalu meniru dan meneladani sikap dari orang dewasa. Apabila orang tua berperilaku sopan santun anak akan menirunya, dan apabila orang tua mereka berperilaku jujur anak akan tumbuh perilaku yang jujur, dan seterusnya. ${ }^{35}$. dalam kajian psikologi, banyak ahli berpendapat bahwa proses meniru ini adalah pada tahap modeling. Modeling paling dekat dalam lingkungan keluarga adalah peran dari orang tua sendiri. Orang tua memiliki perang penting dalam memberikan contoh yang baik kepada anak-anaknya, baik itu dari perilaku, sikap, berperilaku jujur, sholat, mengaji. Anak akan mengikuti atau meniru perilaku yang di tunjukkan oleh orang tua, apabila orang tua tersebut menunjukkan sikap atau perilaku yang kurang baik, anak juga akan menirunya.

${ }^{33}$ Eryzal Novrialdy, "Kecanduan Game Online pada Remaja: Dampak dan pencegahannya", Buletin Psikologi, Vol. 27, Nomor 2, 2019, hlm. 153.

${ }^{34}$ Dina Zakiyah dkk, "Online Game Addition and Pattern of Parents About Students of Al-Muttaqin MTS Pekanbaru”, JOM FKIP-UR, Vol. 5, Nomor 2, Juli - Desember 2018, hlm. 4.

35 Muhammad Nur Abdul Hafizh Suwaid, Prophetic Parenting:Cara Nabi SAW Mendidik Anak, (Yogyakarta: Pro-U Media, 2010), hlm. 140. 
Dari hasil wawancara peneliti, dengan salah satu remaja di dapatkan hasil bahwa orang tua senantiasa mengajak anaknya untuk beribadah. Dari pengamatan observasi yang peneliti lakukan di lapangan, orang tua telah menunjukkan sikap keteladanan tersebut kepada anaknya yang ditunjukkan melalui sikap mengajak anaknya untuk shalat. namun pada diri anak tidak diikuti sepenuhnya dan tetap pada aktifitasnya dalam bermain HP (game online).

Sesi wawancara pada salah satu orang tua didapatkan informasi bahwa orang tua mengajarkan banyak hal diantaranya bagaimana bersosialisasi dalam lingkungan, sopan dan santunn terlebih ketika berbicara dengan orang yang lebih tua, kasih dan sayang pada sesama khususnya pada anak yang lebih kecil, berbicara lemah lembut, serta yang paling prioritas adalah kegiatan agama melalui ritual-ritual keagamanaan (shalat dan mengaji).

2. Metode Kebiasaan

Kebiasaan dari orang tua dan anggota keluarga lainnya merupakan pemberi andil yang besar dalam membentuk akhlak anak. Dalam hal kebiasaan ini, terkait yang diajarkan atau yang diterapkan oleh orang tua sangat berpengaruh terhadap perilaku, kehidupan anak. Kebaikan yang dilihat dari perilaku orang tua yang ditunjukkan melalaui pembelajaran maupun kebiasaan dapat bermanfaat untuk dirinya sendiri maupun orang lain sehingga kebiasaan itu akan menetap pada diri remaja tersebut. Berdasarkan hasil wawancara dengan beberapa remaja dilapangan didapatkan hasil bahwa orang tua mengingatkan untuk mengutamakan pekerjaan dan tugas-tugas serta kegiatan agama untuk diselesaikan dijalankan. Wawancara dengan salah satu orang tua juga didapatkan hasil bahwa orang tua tetap pada ikhtiar untuk mengingatkan anak pada kewajibankewajibannya.

3. Metode Nasihat

Dalam metode nasihat ini anak bisa berfikir lebih baik dan mendorong anak untuk lebih maju, memiliki pedoman tentang ajaran agama islam yang ditunjukkan oleh orang tua secara lisan. Ketika anak pergi ke sekolah atau bermain dengan temannya orang tua selalu membekali pengarahan pada anak agar tidak meninggalkan shalat, berkata jujur, dan tidak melanggar ajaran agama.

Dalam hal ini, orang tua adalah salah satu guru terbaik dalam mendidik anakanaknya dimana orang tua sangat memiliki perang penting dalam menasihati setiap perilaku yang dianggap menyimpang pada diri anak, baik itu terkait tentang shalat, belajar, tugas sekolah, dan bermain. ${ }^{36}$ Observasi dilapangan memperlihatkan remaja yang bermain game online di Lingkungan Taman Pagesangan banyak menyita waktu untuk bermain. Dalam hal ini, orang tua dapat berperan dalam memberikan pilihan lain atau

36 Muhammad Nur Abdul Hafizh Suwaid, Prohetic Parenting: cara Nabi SAW mendidik anak, (Yogyakarta: Pro-U Media, 2010), hlm. 144. 
menyarankan aktivitas lain selain bermain game online kepada anak. Hasil wawancara pada sebagian besar responden remaja didapatkan hasil bahwa tidak ada saran atau sikap orang tua dalam memberikan alternatif kegiatan lainnya yang dapat dilakukan oleh anak. Saran yang diberikan oleh orang tua hanya pada batas bermain HP (game online).

Pada sebagian kecil wawancara dengan responden, didapatkan hasil yang kontradiksi dengan sikap orang tua yang dominan. Sikap yang ditunjukkan dalam ranah ini adalah memebrikan alternative pilihan bagi anaknya selain bermain game online seperti kegiatan yang bisa menambah ilmu bagi pendukung kegiatannya disekolah (membaca dan sebagainya).

4. Metode Perhatian

Orang tua harus selalu memperhatikan perilaku anak-anaknya, apabila anak melalaikan kewajiban maka orang tua akan mengingatkan dengan bahasa yang halus. Mengawasi dan memperhatikan kesiapan mental dan sosial. Dalam perhatian terdapat beberapa aspek antara lain: kognitif, afektif, emosional, dan spiritual. Orang tua harus sabar, lemah lembut dalam memperhatikan perilaku anaknya. Perhatian dalam mengingatkan anak untuk mengerjakan tugas sekolah, shalat, mengaji dengan menggunakan bahasa yang baik tanpa harus berbuat kasar atau dengan kekerasan karena orang tua juga harus memperhatikan sisi psihis dan karakter anak. ${ }^{37}$

Dalam hal bermain game online anak juga membutuhkan perhatian agar tidak kecanduan game online, di Lingkungan Taman Pagesangan beberapa remaja tidak ada pengawasan ataupun kontrol dari orang tua saat bermain game online. Ia bermain game tanpa adanya batasan waktu yang diberikan oleh orang tuanya.

5. Metode Hukuman

Permasalahan-permasalahan yang muncul akibat dari perilaku bermain game online secara berlebihan mendorong dibutuhkan intervensi keluarga untuk mencegah adanya kecanduan game online. Hal tersebut menjadi penting bagi orang tua agar secara intens secara tidak langsung dapat menjalin komunikasi dengan anaknya. Hukuman diberikan sebagai tindakan tegas dalam sisi punishment dalam tujuan agar anak berjalan dijalan yang benar serta dapat memperbaiki diri dan kesalahan. Metode hukuman yang baik pada anak yaitu: memberikan hukuman dengan cinta dan lemah lembut serta tidak menjaga kebiasaan yang salah.

Anak yang memiliki perilaku menyimpang seperti bermain game online dalam waktu yang sangat lama adalah sikap yang negatif. Dengan adanya hukuman atau sangsi anak

${ }^{37}$ HM. Taufiqi, Religius Parenting; Hypnoteaching and Hypnotherapy for Brilian Kids, (Malang: CV Media Sutra Atiga), hlm. 64. 
bisa mengambil pembelajaran terkait hal-hal yang dapat merugikan dirinya sendiri. ${ }^{38}$ Berdasarkan hasil wawancara didapatkan hasil bahwa dominan orang tua memberikan hukuman kepada anak yang menggunakan HP (bermain game) terlalu lama. Bentuk hukuman inipun bervariasi pada masing-masing responden diantaranya adalah pengambilan hak anak seperti pemotongan uang belanja anak atau sampai pada pemberhentian diberikannya uang jajan, dan pengambilan HP yang digunakan oleh anak untuk bermain game online.

Namun pada beberapa kasus berdasarkan informasi dari orang tua, fenomena hukuman ini bertentangan dengan hati nurani orang tua yang selalu ingin melihat anaknya senang. Terkadang disaat hukuman tersebut berlangsung, orang tua kembali menarik hukumannya dengan alasan kasih dan sayangnya kepada anak.

\section{KESIMPULAN}

Berdasarkan hasil dari pengumpulan data, analisis data dan pembahasan yang telah disajikan diatas, didapatkan beberapa kesimpulan pada kasus kecanduan game online pada remaja. Remaja yang kecanduan game online bermain game lebih dari 3 jam dalam sehari, masing-masing remaja memilik durasi waktu bermain game yang berbeda-beda mulai dari 3 jam sampai18 jam dalam sehari. Kecanduan didalam bermain game menyebabkan beberapa hal pada pelakunya salah satunya yang paling dominan terlihat adalah tertundanya aktivitas yang lain. Kegiatan-kegiatan atau aktifitas yang tertunda ini relative dan bergantung pada kewajiban masing-masing remaja. Ketertundaan aktifitas-aktifitas yang lain diantaranya seperti kegiatan ibadah atau keagamanaan, kewajiban-kewajiban sebagai seorang pelajar seperti belajar dan penyelesaian tugas-tugas sekolah lainnya, ketertundaan kegiatan diri sebagai seorang anak seperti tugas-tugas rumah yang telah ditetapkan oleh ornag tua. Selain hal tersebut, kegiatan bermain game yang dilakukan oleh anak menyebabkan kesempitan dalam bersosialisasi. Dalam bermain game, anak lebih lebih memilih untuk sendiri sehingga pergaulan secara fisik sangat terbatas diantara mereka.

Pola asuh orang tua memberikan pengaruh dalam pembentukan perilaku dan perkembangan remaja yang bermain game online. Pengawasan dan control orang tua yang lemah bisa menyebabkan hambatan dalam proses perkembangan, kepribadian yang tidak matang secara sosial, emosional dan spiritual yang mengakibatkan anak tidak bisa mengembangkan hubungan yang harmonis dengan orang lain. Pola asuh yang menekankan pada pola asuh secara islam dan dilaksanakan secara aktif dan terkontrol serta terus menerus dapat menekan perilaku anak dalam kecanduan atau ketergantungannya terhadap HP atau bermain game online. Namun jika metode pengasuhan secara islam diatas diterapkan terputus-

${ }_{38}$ M. Fauzul Adhim, Bersikap terhadap Anak (Pengarub Perilaku Orang Tua terhadap Kenakalan Anak), (Yogyakarta: Titian Ilahi Press, 1997), hlm. 102. 
putus serta tidak meksimal menyangkut keseluruhan aspek metode mengakibatkan anak stagnan pada posisinya dalam bermain HP (game online) sehingga akhirnya memunculkan perilaku ketergantungan terhadap kegiatan tersebut. Beberapa metode yang dimaksud diatas adalah; keteladanan sebagai orang tua, kebiasaan orang tua, nasihat dan hukuman serta perhatian yang berikan oleh orang tua.

\section{DAFTAR PUSTAKA}

Asosiasi Penyelenggara Jasa Internet Indonesia-APJII, dalam https://apjii.or.id/ content/read/39/27/PROFIL-PENGGUNA-INTERNET-INDONESIA-2014, diakses tanggal 14 April 2021.

Abdul Khakim, Miftahul Munir, "Islam Parenting: Aktualisasi Pendidikan Islam dalam Tafsir Q.S. Luqman”. Jounal of Islamic Education (JIE), Vol. 3, Nomor 2, November 2018.

Ahmad Yani dkk, "Implementasi Islam Parenting dalam Membentuk Karakter Anak Usia Dini di RA At-Taqwa Kota Cirebon". AWLADY:Jurnal Pendidikan Anak, Vol. 3, Nomor 1, Maret 2017.

Candra Zebeh Aji, Berburu Rupiah Lewat Game Online, (Yogyakarta: Bouna Books, 2012), hlm. 1.

Chaplin, James P, Kamus Lengkap Psikologi. Jakarta: Rajawali Pers, 2014.

Cesaria Septa Nirwanda, Annastasia Ediati, "Adiksi Game Online dan Keterampilan Penyesuaian Sosial pada Remaja”. Jurnal Empati, Vol. 5, Januari 2016.

Dona Febriandari dkk, "Hubungan Kecanduan Bermain Game Online terhadap Identitas Diri Remaja". Jurnal Keperawatan Jiwa, Vol. 4, Nomor 1, Mei 2016.

Desi Kurnia Sari, "Pola Asuh Orang Tua pada Anak yang Berperilaku Agresif”. Jurnal Ilmiah Potensia, Vol. 3, Nomor 1, 2018.

Dewa Ayu Eka dkk, "Hubungan Pola Asuh terhadap Perilaku Game Online di SMK Kesehatan PGRI Denpasar”. Jurnal, Agustus 2019.

Dina Zakiyah dkk, "Online Game Addition and Pattern of Parents About Students of AlMuttaqin MTS Pekanbaru”. JOM FKIP-UR, Vol. 5, Nomor 2, Juli - Desember 2018.

Eryzal Novrialdy, "Kecanduan Game Online pada Remaja: Dampak dan pencegahannya". Buletin Psikologi, Vol. 27, Nomor 2, 2019.

Hikmatullah, Teguh Fachmi, "Keteladanan Orang Tua dalam Islam”. Jurnal Pendidikan Agama Islam, Vol. 07, Nomor 2, Juni-Desember 2020.

HM. Taufiqi, Religius Parenting; Hypnoteaching and Hypnotherapy for Brilian Kids. Malang: CV Media Sutra Atiga.

Irawan Soehartono, Metode Penelitian Sosial. Bandung: PT Remaja Rosdakarya, 2004.

Iskandar, Metodelogi Penelitian dan Sosial. Jakarta: Refrensi, 2013.

Jusuf Tjahjo Purnomo, Yohanes Rikky Dwisantoso, "Hubungan Kecanduan Game Online terhadap Penyesuaian Sosial pada Remaja”. Jurnal Humaniora Bina Darma, Vol. 4, Nomor 1, Januari-Juni 2017.

Juwi Rayfana Tiwa dkk, "Hubungan Pola Asuh Orang Tua dengan Kecanduan Game Online pada Anak Usia Remaja Di SMA Kristen Zaitun Manado”. e-journal Keperawatan (e-Kp), Vol. 7, Nomor 1, Mei 2019.

Krista Surbakti, "Pengaruh Game Online Terhadap Remaja". Jurnal Curere, Vol. 01, Nomor 01, April 2017. 
Maria Agustina Lebho dkk, "Perilaku Kecanduan Game Online Ditinjau dari Kesepian dan Kebutuhan Berafiliasi pada Remaja". Journal of Health and Behavioral Science, Vol. 2, Nomor 2, September 2020.

Maurice Andrew Suplig, "Pengaruh Kecanduan Game Online Siswa SMA Kelas X terhadap Kecerdasan Sosial Sekolah Kristen Swasta di Makassar”. Jurnal Jaffray, Vol. 15, Nomor 2, Oktober 2017.

Mahmud dkk, Pendidikan Agama Islam dalam Keluarga. Jakarta: Akademia, 2013.

Meike Makagingge dkk, "Pengaruh Pola Asuh Orang Tua terhadap Perilaku Sosial Anak". Yaa Bunayya: Jurnal Pendidikan Anak Usia Dini, Vol. 3, Nomor 2, November 2019.

Moh. Haitami Salim, Pendidikan Agama dalam Keluarga. Yogyakarta: Ar-Ruzz Media, 2013.

M. Fauzul Adhim, Bersikap terhadap Anak (Pengarub Perilaku Orang Tua terhadap Kenakalan Anak). Yogyakarta: Titian Ilahi Press, 1997.

M. Burhanuddin Ubaidillah, "Pendidikan Islamic Parenting dalam Hadith Perintah Salat". Jurnal Darussalam: Jurnal Pendidikan, Komunikasi dan Pemikiran Hukum Islam, Vol. 10, Nomor 2, April 2019.

Muhammad Nur Abdul Hafizh Suwaid, Prophetic Parenting: cara Nabi SAW mendidik anak. Yogyakarta: Pro-U Media, 2010.

M. Thalib, "Pola Asuh Orang Tua; Perspektif Konseling dan Al-Qur'an”. Jurnal Hunafa, Vol. 4, Maret 2015.

Mimi Ulfa, "Pengaruh Kecanduan Game Online Terhadap Perilaku Remaja Di Mabes Game Center Jalan HR. Subrantas Kecamatan Tampan Pekanbaru". Jurnal JOM. FISIP, Vol. 4, Nomor 1, Februari 2017.

Newzoo, “The Indonesian Gamer", dalam newzoo.com, diakses tanggal 11 juni 2021

Octa Reni Setiawati, Agin Gunado, "Perilaku Agresif pada Siswa SMP yang bermain Game Online”. Psikologi Malahayati, Vol. 1, Nomor 1, Maret 2019.

Rosi Kusumawati dkk, "Perbedaan Tingkat Kecanduan (Adiksi) Game Online pada Remaja Ditinjau dari Gaya Pengasuhan". RAP UNP, Vol. 8, Nomor 1, Mei 2017.

Rizky Anggraini, "Dampak Pengasuhan Orang Tua yang Kecanduan Game Online terhadap Perkembangan Anak". Welfare: Jurnal Ilmu Kesejabteraan Sosial, Vol. 7. Nomor 2, 2018.

Syaiful Bahri Djamarah, Pola Asuh Orang Tua dan Komunikasi dalam Keluarga, Upaya Membangun Citra Membentuk Pribadi Anak. Jakarta: Rieneka Cipta, 2014.

Siprianus Koi dkk, "Pengaruh Permainan Game Online terhadap Aktivitas Belajar pada Anak Usia Sekolah Kelas III dan IV SDN Merjosari Malang”. Nursing News, Vol. 2, Nomor 1, 2017.

Tantri Widyarti Utami, "Kecanduan Game Online Berhubungan dengan Penyesuaian Sosial pada Remaja”. Jurnal Keperawatan, Vol. 12, Nomor 1, Maret 2020.

Yudrik Jahja, Psikologi Perkembangan. Jakarta: Kencana Prenadamedia Group, 2011. 